\title{
EUROPE'S COMMON FOREIGN AND SECURITY POLICY: FACING CRISES IN UKRAINE AND SYRIA
}

\author{
Eric Engle \& Tetiana Danyliuk
}

\begin{abstract}
This paper outlines the institutions which form and implement the Common Foreign and Security Policy of the European Union (EU CFSP) and examines the history of the EU CFSP. Descriptively, it explains the increasing cohesion of the CFSP as a reaction to past failures. Prescriptively, it recommends ways in which the CFSP can focus European will to attain desirable objectives of peace, prosperity, and protection of human rights. It compares the current conflict in Syria to the past failure of the EU to manage a similar conflict in Yugoslavia. It argues that the EU is contributing to the resolution of conflicts in Ukraine but it is unlikely that the EU can contribute to the peaceful transition of power in Syria as mediator between the U.S. and Russia or Assad and Rebels. Unlike Ukraine, paralysis, incapacity, and disintegration of the failing state are likely outcomes in Syria. EU CFSP institutions and instruments are well considered and consensusoriented but are slow and even indecisive in consequence. The crisis in Ukraine will likely focus the political will of European élites to attain decisive, coherent foreign policies adapted to the challenges presented in Ukraine and Syria. The death of Syria and the agony of Ukraine are bad for business - and even worse for peace and human rights. The EU has suasive and dissuasive soft-power mechanisms (education, sanctions), and NATO has hard power instruments (soldiers, aircraft). In concert with EU trading partners a resolution of these crises will be found - but the cost in blood and lost business is yet to be accounted for.
\end{abstract}




\section{INTRODUCTION}

The European Union is increasingly assuming the character of a state. The core members of the European Union have common customs, a single currency (the Eurozone), and common border controls (Schengen Area). The European Union also has a Common Foreign and Security Policy ("CFSP”) and a Common Security and Defence Policy (“CSDP”) with corresponding institutions. This article provides an overview of the institutional structure and historical experiences of the CFSP and argues that EU foreign policy is becoming more cohesive and will continue to do so thanks to the functionalist method $^{1}$ and globalization.

Although it is growing more coherent, EU foreign policy has not been cohesive in the past. ${ }^{2}$ This can be seen in the crises involving Yugoslavia, including the recognition of successor states to the Yugoslavian state. ${ }^{3}$ Today in Syria and Ukraine, there is a real risk of a reoccurrence of the Yugoslavian tragedy: paralysis, inaction, and avoidable bloodshed. United Nations Security Council paralysis, thanks to Russian vetoes, may once again meet European political paralysis in the face of Russian covert action (arming of rebels, funding of extremist ideologues, dispatching mercenaries and volunteers), leading to grave human rights violations and state fragmentation. The importance of examining EU foreign policy to prevent a repeat of the Yugoslavian scenario in Syria or Ukraine becomes even more evident when one remembers the risk of terrorism. There is a chance to avoid the repetition of the pattern of paralysis and needless bloodshed in Syria and Ukraine because EU foreign policy is growing more cohesive, and the crisis in Ukraine clearly concentrates CFSP and directs it toward the North Atlantic Treaty Organization ("NATO”). Conscious analysis of hard facts and concentration of political will are prerequisites to the resolution of the crises in Syria and Ukraine.

European foreign policy is at times absent on the world stage because of internal political splits among the EU Member States. One result of this political disunity is that little or no effective military means are available ${ }^{4}$

\footnotetext{
1 See, e.g., Robert Schuman, The Schuman Declaration (May 9, 1950), available at http://europa.eu/about-eu/basic-information/symbols/europe-day/schuman-

declaration/index_en.htm ("Europe will not be made all at once, or according to a single plan. It will be built through concrete achievements which first create a de facto solidarity.”).

${ }^{2}$ Ian Ward, The Challenges of European Union Foreign and Security Policy: Retrospective and Prospective, 13 Tul. J. Int'l \& Comp. L. 5, 46 (2005) (pointing out that "a coherent European foreign policy remains more of an aspiration than a current reality.”).

${ }^{3}$ Sergio Baches Opi \& Ryan Floyd, A Shaky Pillar of Global Stability: The Evolution of the European Union's Common Foreign and Security Policy, 9 CoLUM. J. EuR. L. 299, 304-07 (2003).

${ }^{4}$ Ministry for Foreign Affairs, Goals for Civilian and Military Capabilities, Gov'T OfFICES OF SwED., http://www.government.se/sb/d/11241/a/116838 (last updated Dec. 3, 2008) ("The Union has no civilian or military capabilities of its own for conducting peace-support
} 
within a purely EU framework. Rather, NATO does the heavy lifting in security issues. However, if there is coherent common political will, then the means to implement that common agenda can be found. Another precondition to a coherent common foreign policy is a common identity. Common identity may be based on language, race, religion, ideology, or something else entirely: Europe is a nation of peoples. The sense of common interest among the European people-which does exist-is also a precondition to a common foreign policy. These constraints limit and condition the formation of a common strategy in foreign policy.

Most institutions of the European Union are deficient in democratic input. Some scholars, while acknowledging the problem of democratic deficit and national diversity, nevertheless argue that Europe can and should aim to become a superpower ${ }^{5}$ "whether to oppose the United States, oppose terrorism," 6 or create a common European identity. "Those objectives are somewhat unrealistic because they exceed European military abilities." 8 Europe certainly has the economic means to world power, due to the euro, and is a global economic actor enjoying a secondary reserve currency. European arms are technologically roughly equivalent to U.S. arms and are probably superior to Russian arms in quality, though not in reliability. Yet, Europe does not have the capacity to project military power globally, let alone to field large combined arms forces halfway around the world for years at a time. Finally, the likelihood of Europe leaving NATO or forming a tenable alternative to NATO is nil. Transatlantic liberal values of individual freedom and market economics, as well as common heritage, explain why Europe and the United States will draw closer together, particularly given the challenges liberalism faces from the authoritarian populism of Putin and LePen and fanatical religious extremism.

operations. Instead, operations are conducted with personnel and equipment that the Member States make available to the Union in each individual case.").

${ }^{5}$ Mark C. Anderson, A Tougher Row To Hoe: The European Union's Ascension as a Global Superpower Analyzed Through the American Federal Experience, 29 SYRACUSE J. INT’L L. \& CoM. 83, 118-19 (2001).

${ }^{6}$ Ward, supra note 2, at 37 (“According to Romano Prodi, one of the essential goals of the European Union is to create a superpower on the European continent that stands equal to the United States. To a certain extent, the challenge carries an antagonistic edge. Samuel Huntington famously described a prospective 'clash of civilizations' between the 'West' and 'Islam.' More recently, it has been posited that there might be an equally vital 'clash' within western 'civilization', between the 'soft' power of Europe and the 'hard' power of the United States, the multilateralism of the former and the unilateralism of the latter.").

${ }^{7}$ Opi \& Floyd, supra note 3, at 299.

${ }^{8}$ Elizabeth Shaver Duquette, The European Union's Common Foreign and Security Policy: Emerging from the U.S. Shadow?, 7 U.C. DAVIS J. INT'L L. \& POL’y 169, 191 (2001), (“For the situation to improve, it was suggested that capabilities increase or expectations lower. In other words, the Union would either have to revamp its decision making process and build an effective military force and command structure, or it would have to scale back its foreign policy goals and revise the image it portrays to third countries.”). 
As mentioned above, a cohesive foreign policy that can prevent a recreation of the Yugoslavian debacle in Syria or Ukraine will align expectations with abilities to express a common political will arising out of a common identity. The "Weimar Triangle" approach seems effective thereto. A common European foreign policy is necessary to struggle most effectively for peace ${ }^{9}$ through the rule of law and open trade. "A common foreign policy is also necessary to secure the collective interests of all Europeans: without a common foreign policy, Europe will remain divided, irrelevant on the world stage, and powerless.” 10

We examine European foreign policy to understand the opportunities and challenges it presents and to determine how best to shape it to help solve current problems, notably the crises in Syria and Ukraine. To this end, we look at the institutions and instruments of European foreign policy and then at the historical experiences and contemporary issues.

\section{UNDERSTANDING THE FORMATION OF EUROPEAN FOREIGN POLICY}

\section{A. Methodology}

We can better understand EU foreign policy in terms of institutional specialization (functionalism) and history (materialism), since these methods provide practical contexts for understanding complex conflicting social interactions.

\section{Functionalism}

Functionally, EU foreign affairs institutions and policies are pragmatic and progressing. Europe's foreign policy through use of the functionalist method, attaining what is possible here and now in specific fields, yet always seeking to gain ground and legitimacy through its success in every field it enters. Functionalism is like a ratchet: progress may be slow, but it is certain and irreversible. Thus, Europe's foreign policy is more cohesive now than in the past, and it will be more cohesive in the future.

\footnotetext{
${ }^{9}$ Donato F. Navarrete \& Rosa María F. Egea, The Common Foreign and Security Policy of the European Union: A Historical Perspective, 7 Colum. J. Eur. L. 41, 41 (2001) ("European history has taught us two lessons. The first is that the unification of Europe has not been achieved by armed force despite the various attempts to do so over the last two centuries [e.g., Napoleon, Hitler, etc]. The second, which also serves to explain the failure of these attempts, is that the countries of Europe have used every possible means to prevent the emergence of a preeminent power among them, which could threaten their security. The corollary of these two ideas is clear: European unification must be achieved through the independence and freedom of its people or be condemned to failure.”).

${ }^{10}$ Anderson, supra note 5, at 83-84 ("In fact, the EU could very well languish indefinitely as 'an economic giant with the political influence of a pygmy' if the Member States, through their leadership, do not take concrete steps to address them.”).
} 
A correct perspective sees the sweep of history, not just the present point. Europe is a union of states-in modern terms, an international organization; in historic terms, a compound confederation. The European Union and its member states have international legal personality, which was the case of compound confederations, unlike federations, which are permanent unions and where the international personality is exclusive to the federation. As time has passed, Europe's foreign affairs institutions and policies have developed and improved their interaction. ${ }^{11}$ Member states will increasingly coordinate their foreign policies and even transfer more of their competencies related to this area to the Union. ${ }^{12}$

The CFSP coordinates and harmonizes the foreign policies of the member states. It is a hybrid approach that is neither federal nor national; in our opinion,, it is confederal. The CFSP is a state-inspired model carried out by states eager to emphasize the institutional and ideological limits of EU foreign policy. It has aspects that are both supranational and intergovernmental. This surprising mix leads "to acts whose significance and repercussions cannot be easily defined by our traditional legal vocabulary.”"13

\section{Historical Materialism}

Historically, the origins of the CFSP can be traced back to common trade policy. ${ }^{14}$ European Union foreign policy started from mere common commercial policy and grew to include a ministry of foreign affairs (the EEAS), a ministerial post for foreign relations (the High Representative), and a Common Defense and Security Policy for the coordination of military assets. The European Union has a foreign policy apparatus, and it is definitely developing into a state-like body with full foreign policy capacity. In this approach, the correct focus is on the dynamic process of change, the trend, rather than any static point in time. If John F. Kennedy's ghost needs to call Europe, there is finally someone at the other end of the line.

\section{B. Forming the CFSP}

The CFSP is the implementation of a cohesive perspective on international relations that expresses an ideology of liberal internationalism on the basis of the functional method through an articulated mix of policy choices.

\footnotetext{
11 John J. Kavanagh, Attempting to Run Before Learning to Walk: Problems of the EU's Common Foreign and Security Policy, 20 B.C. INT’L \& CoMP. L. REV. 353, 356-57 (1997).

12 Opi \& Floyd, supra note 3 , at 320.

13 Panos Koutrakos, Constitutional Idiosyncrasies and Political Realities: The Emerging Security and Defense Policy of the European Union, 10 ColuM. J. EUR. L. 69,80 (2003).

${ }^{14}$ Denis Chaibi, The Foreign Policy Thread in the European Labyrinth, 19 CoNN. J. INT’L L. 359, 367 (2004).
} 


\section{Ideology}

The European Union seeks to attain desired collective goals such as defense of basic human rights outside Europe,${ }^{15}$ the inculcation of a global rule of law culture, ${ }^{16}$ and the attainment of peace through prosperity brought about by open borders and economic interdependence. Ukraine is the next victory of liberalism freeing human potential to fully flourish under the rule of law. The European Union seeks to attain these practical, hopeful objectives by coordinating the foreign policies of the member states. The general provisions of the CFSP are in Article 24 of the Treaty on European Union (TEU), which states:

The Union's competence in matters of common foreign and security policy shall cover all areas of foreign policy and all questions relating to the Union's security, including the progressive framing of a common defence policy that might lead to a common defence. The common foreign and security policy is subject to specific rules and procedures. It shall be defined and implemented by the European Council and the Council acting unanimously, except where the Treaties provide otherwise. The adoption of legislative acts shall be excluded. The common foreign and security policy shall be put into effect by the High Representative of the Union for Foreign Affairs and Security Policy and by Member States, in accordance with the Treaties.

Interestingly, Article 24 represents a broadening of the Union's foreign policy competencies both in its objectives (which explicitly include defense) and in the means used to attain such goals (through the creation of the High Representative) ${ }^{17}$ This is particularly evident if Article 24 is compared to the

\footnotetext{
${ }^{15}$ E.g., Regulation (EC) No 1889/2006, of the European Parliament and of the Council of 20 December 2006 on Establishing a Financing Instrument for the Promotion of Democracy and Human Rights Worldwide, 2006 O.J. (L 386) 1, available at http://eurlex.europa.eu/LexUri Serv/LexUriServ.do?uri=OJ:L:2006:386:0001:0011:EN:PDF.

${ }^{16}$ E.g., Council Decision 2012/291/CFSP, of 5 June 2012 Amending and Extending Joint Action 2008/124/CFSP on the European Union Rule of Law Mission in Kosovo, EULEX KOSOVO, 2012 O.J. (L 146) 46, available at http://www.eulex-kosovo.eu/docs/LexUriServ -2012.pdf.

${ }^{17}$ Gerrard Quille, The Lisbon Treaty and its Implications for CFSP/ESDP, at 4. (Feb. 2008) ("As a Vice-President of the Commission, the European Parliament extends its role over the High Representative both in requiring its consent on the appointment (article 9D paragraph 6 and 8 ) of the whole Commission and in his/her dismissal through the censure procedure for the whole Commission (Article 201.2 Treaty on the Functioning of the European Union TFEU).") (emphasis omitted), available at http://www.europarl.europa.eu/document/ activities/cont/200805/20080513ATT28796/20080513ATT28796EN.pdf.
} 
previous version of Article 11 of the treaty; aspirational goals such as democracy, rule of law, human rights, and open borders now appear in Article 21 of the treaty.

\section{Typology of CFSP Decisions}

Earlier, the European Union had structured its CFSP as a hierarchy of common strategies, common positions, and common actions. That was a logical approach, but the terminology has changed, slightly, probably for political reasons. The CFSP is now expressed as a variety of decisions. ${ }^{18}$ The most general policies with the broadest coverage are the strategic objectives and interests of the European Union, which are decided upon by the European Union ${ }^{19}$ (in particular by the European Council). ${ }^{20}$ The objectives and interests may then be expressed as EU positions. ${ }^{21}$ The objectives, interests, and positions in turn may be implemented through actions (operations). Actions include operations in the fields of conflict prevention and crisis management, non-proliferation and disarmament, conflict resolution, verification, support for the peace process and stabilization, and the dispatching of European Union Special Representatives.

\section{FOREIGN POLICY INSTITUTIONS}

We will further examine the EU political institutions, which define foreign policy because foreign policy is generally political and nonjusticiable as opposed to legal and reviewable. ${ }^{22}$ Then, we will analyze

${ }^{18}$ European Policies: Common Foreign and Security Policy, Europa, http://europa.eu/ legislation_summaries/institutional_affairs/treaties/lisbon_treaty/ai0025_en.htm (last updated Apr. 26, 2010) ("The Treaty of Lisbon modifies the types of act adopted in the field of the CFSP. The previous instruments such as common strategies, common positions and common actions are replaced. Henceforth, the European Council and the Council of the EU shall only adopt decisions on: the strategic interests and objectives of the Union; the actions to be undertaken by the Union; the positions to be taken by the Union; the procedures for implementing the actions and positions of the Union.”).

${ }^{19}$ Treaty on European Union, art. 21.2, Feb. 7, 1992, E.T.S. 35 [hereinafter TEU].

${ }^{20}$, TEU, supra note 19 , at art. 22.

21 Derek E. Mix, Cong. Research Serv., R41959, The European Union: Foreign and SECURITY POLICY 6-7 (2013), available at http://fas.org/sgp/crs/row/R41959.pdf. ("The Lisbon Treaty reconceptualizes CFSP instruments into four types of Decisions: (1) on the strategic objectives and interests of the EU, (2) on common positions, (3) on joint actions, and (4) on the implementing arrangements for common positions and actions. Elements of CFSP produced after December 2009 are therefore officially termed Decisions.”).

${ }^{22}$ European Policies: Common Foreign and Security Policy, supra note 18 (divesting the Court of Justice of review powers with respect to the CFSP with exceptions intended to prevent abuse such as permitting review of the legality of sanctions against individual natural or legal persons). This could be seen as an EU version of the U.S. constitutional "political question doctrine". 
various security institutions to understand the relations among these institutions, which are responsible for forming and implementing the CFSP.

\section{A. Political Institutions}

Institutionally, European foreign policy is created and implemented under the rubric of the CFSP. ${ }^{23}$ Initially, the CFSP was not equivalent to state foreign policy. ${ }^{24}$ However, it increasingly approaches that goal. While in the past, one might have argued that Europe has no foreign policy, ${ }^{25}$ that position is really no longer tenable. Europe does not yet have a foreign policy in the traditional or federal sense of a hierarchically superior final authority with an integrated diplomacy and military apparatus. Europe does, however, have the equivalent to a Minister of Foreign Affairs: the High Representative of the Union for Foreign Affairs and Security Policy, Catherine Ashton), ${ }^{26}$ a foreign service, ${ }^{27}$ the European External Action Service), ${ }^{28}$ and a permanent President of the Council, ${ }^{29}$ who ensures representation of the Union overseas without prejudice to the High Representative of the Union for Foreign Affairs and Security Policy. ${ }^{30}$ These coordinating mechanisms resemble those of a

23 See Mamedov Muschwig, Crisis of Transatlantic Relations: NATO and the Future European Security and Defense Identity (ESDI), 10 U. MiAmI INT'L \& CoMP. L. REV. 13, 19 (2002).

${ }^{24}$ Id. at 37.

${ }^{25}$ Eric Stein, European Foreign Affairs System and the Single European Act of 1986, 23 INT’L L. 977, 992 (1989).

${ }^{26}$,Foreign Policy, Consilium, http://www.consilium.europa.eu/policies/foreign-policy?lang =en (last visited Mar. 31, 2013) ("With the entry in into force of the Lisbon Treaty (2009) the post of High Representative of the Union for Foreign Affairs and Security Policy was created. This post combines three functions: the EU's representative for the CFSP, the President of the Foreign Affairs Council and a Vice-President of the Commission. At the moment, this post is held by Catherine Ashton.").

${ }^{27}$ Wolfgang Wessels \& Franziska Bopp, The Institutional Architecture of CFSP After the Lisbon Treaty: Constitutional Breakthrough or Challenges Ahead? 10 CEPS CHALLENGE PAPER 23, 27 (June 2008) ("A new institutional arrangement is the 'European External Action Service' (EEAS) which shall assist the High Representative in 'fulfilling his mandate' (Art. 27 (3) TEU) and thus function as a kind of 'ministry' to the re-named 'Foreign Minister.' The EEAS works in cooperation with the national diplomatic services and 'shall comprise officials from relevant departments of the General Secretariat of the Council and of the Commission as well as staff seconded from national diplomatic services of the Member States' (Art. 27 (3) TEU) and thus combine supranational and intergovernmental elements.), available at http://www.ceps.eu/book/

institutional-architecture-cfsp-after-lisbon-treaty-constitutional-breakthrough-or-challenges-a. See European External Action Service, EEAS http://www.eeas.europa.eu/index_de.htm (last visited Oct. 8, 2014).

${ }^{28}$ Quille, supra note 17, at 4. ("The European External Action Service (article 13A) will consist of personnel from the Council General Secretariat, the Commission and seconded staff from national diplomatic services.").

${ }^{29}$ TEU, supra note 19, at art. 9B.

${ }^{30}$ Quille, supra note 17 , at 4. 
state. However, the European Union does not have any military forces, not even the French Foreign Legion, which would be the logical core of a truly European army. Instead, the Common Foreign and Defence Policy (CFDP) looks to the military forces of the member states.

Thus, the key institutions of EU foreign policy are the European Union, the High Representative and the External Action Service, the European Council, the Council, the Commission, the European Parliament, ${ }^{31}$ the President of the Council of the European Union, and the Member States. They form and implement the strategic objectives and interests of the European Union, EU positions, ${ }^{32}$ and EU actions.

\section{The Member States}

Institutionally, the Member States are vital to the CFSP both because of the principle of subsidiarity and the fact that currently there is no EU military: the European Union relies on its Member States for military force. Furthermore, as national security is a core aspect of sovereignty with real risks, member states are understandably cautious regarding any transfer of sovereign power in the security field. The Member States can propose objectives, strategies, and positions, ${ }^{33}$ and implement the policies through actions.

\section{The European Union: An International Legal Person with Foreign Policy Competence}

The power and legitimacy of the European Union as an exponent of European foreign policy is based on the fact that it can claim to speak with one voice for all of Europe. Thus, the European Union has auctoritas (actual power), and the Member States have potestas (moral right). These are the two elements of sovereignty, historically speaking.

Typically, an international organization has international legal personality as a result of agreements between states, which create a legal person distinct in powers and purposes from the members and whose objective is to exercise powers in international relations. ${ }^{34}$ The European

\footnotetext{
${ }^{31}$ Chaibi, supra note 14 , at 360.

${ }^{32}$ Mix, supra note 21, at 6-7. ("The Lisbon Treaty reconceptualizes CFSP instruments into four types of Decisions: (1) on the strategic objectives and interests of the EU, (2) on common positions, (3) on joint actions, and (4) on the implementing arrangements for common positions and actions. Elements of CFSP produced after December 2009 are therefore officially termed Decisions.").

${ }^{33}$ TEU, supra note 19, art. 30 (“Any Member State, the High Representative of the Union for Foreign Affairs and Security Policy, or the High Representative with the Commission's support, may refer any question relating to the common foreign and security policy to the Council and may submit to it, respectively, initiatives or proposals.”).

${ }^{34} \mathrm{Id}$. at art. 14.
} 
Union is an international legal person ${ }^{35}$ and has the capacity to negotiate international treaties in given fields. ${ }^{36}$ The European Union can and does negotiate treaties on behalf of the entire Union.

\section{The Presidency of the Council of the European Union and the High Representative (EEAS)}

The President of the European Council represents the European Union in the CFSP, ${ }^{37}$ as does the High Representative. ${ }^{38}$ The President implements general guidelines and strategies. The President holds executive powers.

\section{The European Council}

The European Council brings together the heads of states and the President of the Commission, ${ }^{39}$ who determine the content of the strategic objectives of the CFSP, including common defense and security related matters (CDSP).

Strategic objectives outline the goals of the Union and address activities with specific countries or regions, i.e., how those guidelines are to be implemented. Actions implement the policies outlined in the guidelines and in the strategic objectives. Thus, the European foreign policy instruments are hierarchically arranged from general to specific with differing decision mechanisms for each policy instrument.

\section{The Council of the European Union (the Council)}

The Council consists of EU Foreign Ministers and determines actions and positions. Actions "commit the Member States in the positions they adopt and in the conduct of their activity." 40 Actions are what we typically think of as foreign policy, e.g. to implement a peacekeeping operation. Actions are concrete steps taken to implement the general policies of the guidelines and strategies.

The Council must ordinarily reach its CFSP decisions unanimously. ${ }^{41}$ That is a serious limitation on the ability of the European Union to engage in a coherent forceful foreign policy but was reiterated in the Lisbon Treaty. ${ }^{42}$

\footnotetext{
${ }^{35} I d$. at art. 46A.

${ }^{36}$ Treaty Establishing the European Economic Community, Mar. 3, 1957, art. 281, 300. http://eur-lex.europa.eu/en/treaties/dat/12002E/htm/C_2002325EN.003301.html.

37 TEU, supra note 19, at art. 15(6). 33.

${ }^{38}$ Clive Archer, The European Union, 112 (Routledge, 2008).

${ }^{39}$ TEU, supra note 19 , art. 15(2).

40 TEU, supra note 19 at art. 28(2).

41 TEU, supra note 19 ,at art. 31.

42 Treaty of Lisbon, art. 28A.4, 2007 O.J. (L 306/1) [hereinafter Treaty of Lisbon]; Quille, supra note 17 , at 6 .
} 
Consequently, mechanisms have been introduced to meet this challenge. Member states can abstain from voting, ${ }^{43}$ and abstention from voting will not prevent all other member states from adopting a policy. Similarly, member states can qualify their abstention such that the abstaining party will not be obliged to apply the decision, which will bind all other member states. ${ }^{44}$ Further, in the event the European Union as a whole is not allowed to act, states can act with each other in "enhanced cooperation." 45 However, enhanced cooperation as to matters with military or defense implications is expressly forbidden. ${ }^{46}$ The Lisbon Treaty did not change the funding mechanisms of the $\mathrm{CFSP}^{47}$ : enhanced cooperation is funded by the Member States, not the Union.

Exceptionally, some votes of the Council may be taken by qualified majority. However, qualified majority voting is expressly forbidden as to "decisions having military or defence implications." 48 Further, member states can force a vote to be taken on the basis of unanimity. ${ }^{49}$

\section{The Commission}

Like states, ${ }^{50}$ the Commission can propose guidelines, strategies, actions, and positions. ${ }^{51}$ The Commission is solely responsible for European trade policy, ${ }^{52}$ an important aspect of EU Foreign Policy ${ }^{53}$ for which the European Union has full competence. ${ }^{54}$

\section{The European Parliament}

The European Parliament is the only directly elected EU institution, yet

\footnotetext{
${ }^{43}$ TEU, supra note 19, at art. 31(1). When abstaining in a vote, any member of the Council may qualify its abstention by making a formal declaration under the present subparagraph. In that case, it shall not be obliged to apply the decision.

${ }^{44} I d$.

45 TEU, supra note 19, art. 20(1); Treaty on the Functioning of the European Union art. 329, 2012 O.J. (L 326/49) [hereinafter TFEU]..

46 TFEU, supra note 41, at art. 329(1).

47 The Lisbon Treaty did not change the financing provisions of the Nice Treaty. European Policies: Common Foreign and Security Policy, supra note 18.

48 TEU, supra note 19, at art. 31(4).

49 TEU, supra note 19, at art. 31(3). If a member of the Council declares that, for vital and stated reasons of national policy, it intends to oppose the adoption of a decision to be taken by qualified majority, a vote shall not be taken.

${ }^{50}$ Adrian Toschev \& Gregory Cheikhameguyaz, The European Union and the Final Status for Kosovo, 80 CHI.-Kent L. Rev. 273, 285 (2005).

51 TEU, supra note 19, at art. 22.

${ }^{52}$ Toschev \& Cheikhameguyaz, supra note 50.

${ }^{53}$ Chaibi, supra note 14 , at 393.

54 TEU, supra note 19, at art. 5; TFEU, supra note 41, at art. 207.
} 
it has few powers. ${ }^{55}$ The Parliament can recommend actions to the Presidency and request and receive information from the High Representative regarding the CFSP. ${ }^{56}$ Parliament also has a consultative function and has the power to fund operating expenses of the CFSP.${ }^{57}$ If European foreign policy is to grow into a legitimate and effective instrument expressing the needs and hopes of Europe, then it will be through the parliament and, more exactly, through the struggles over taxation and budgeting that will occur, just as historically happened in Britain. Such struggles are examples of productive disunity.

Both macroeconomic and political forces explain the creation of Europe. Finance recurs as a key issue at the operational level as well. One major weakness of attempts to create a common European foreign policy is the lack of financial resources. ${ }^{58}$ CFSP budgeting is met pursuant to Article 28 of the EU Treaty, which funds operating expenses for the CFSP from the EC budget, excepting expenditures arising from defense operations, ${ }^{59}$ in which case members are to pay proportionate to their national wealth, excluding those states that opt out of those operations. ${ }^{60}$ This gives the European Parliament some influence in foreign policy, namely the "power of the purse." ${ }^{1}$ This funding mechanism "should reduce, if not eliminate, conflicts over procedure between the institutions and thereby ensure increased coherence between the activities of the institutions in the area of the CFSP,"62 though financial issues remain, probably inevitably,

55 Opi \& Floyd, supra note 3, at 311.

${ }^{56}$ TEU, supra note 19 , at art. 36.

${ }^{57}$ Opi \& Floyd, supra note 3, at 321-22.

58 Alan W. Cafruny, A Ruined Fortress? Europe and American Economic Hegemony, 19 CONN. J. INT'L L. 329, 331-32 (2004) (“[C]urrent EU revenues are 1.3 percent of member-state GNP, much less even than the five to seven percent viewed as the minimum necessary budget called for in the McDougal Report of 1977.”).

${ }^{59}$ Navarrete \& Egea, supra note 9.

${ }^{60}$ Opi \& Floyd, supra note 3, at 322. [Ex] Article 28 of the TEU (as amended by the Treaty of Amsterdam) provides as a general principle that all operating expenses of the CFSP shall be directly charged to the EC budget, except for expenditures arising from defense operations and cases where the Council unanimously decides otherwise. In those cases in which expenditure is not charged to the EC budget, it shall be charged to the Member States in accordance with the gross national scale, unless the Council unanimously decides otherwise. Finally, as per expenditure arising from operations having military or defense implications, those Member States which have opted-out in accordance with [Ex] Article 23(1) of the TEU, are not obliged to contribute to the financing thereof.

${ }^{61}$ Chaibi, supra note 14, at 390. Since the CFSP budget is established following the budgetary procedure laid down for the Community budget, the European Parliament has found a way to influence a CFSP from which it is institutionally excluded. This is even more important when the initially forecasted CFSP budget is insufficient. The reinforcement of CFSP appropriations is then executed through either a transfer of appropriations or a supplementary and/or amended budget. In both cases, there is a need for a proposal from the Commission, and the European Parliament has the last word.

${ }^{62}$ Duquette, supra note 8, at 188. 
contentious. ${ }^{63}$

\section{B. Security Institutions}

Implementing the CFSP, specifically its actions, requires common security institutions. However, the existing institutions-NATO and the Rapid Reaction Force ("RRF”) —are inept; they cover too much (NATO) to help build a cohesive union, or they are badly coordinated (RRF, Eurocorps). Nevertheless, Europe has taken the first few faltering steps toward its own security institutions under the CSDP.

\section{NATO}

NATO is the core institution of transatlantic relations. ${ }^{64}$ However, it is only one institution among others. The difficulty in using NATO as an instrument in European foreign policy arises from the fact that some EU Member States are not in NATO, and some NATO states are not in the European Union. ${ }^{65}$ The divergence of membership in NATO and the European Union explains in part the transatlantic tensions that arise regarding the use of NATO resources. ${ }^{66}$ NATO competes with Union institutions and has preempted attempts to establish an independent Western European Security and Defense Initiative. ${ }^{67}$ The TEU respects the member states' NATO commitments, ${ }^{68}$ which are a serious, but perhaps inevitable, constraint on the European Union's foreign policy. As long as most member states are in NATO, the European Union will not need to develop its own institutions; however, NATO could never represent those interests, which are exclusively European and not also transatlantic. In any case, now there is a mutual assistance provision in the TEU. ${ }^{69}$ All Member states are obliged to help any member state which is the victim an armed aggression. Furthermore, the "neutral" states, notably Sweden and Finland but possibly also Austria or even Ireland, may join NATO as a reaction to Russia's illegal annexation of Crimea.

\footnotetext{
${ }^{63}$ Kavaanagh, supra note 11 , at 366.

${ }^{64}$ Muschwig, supra note 23, at 37.

${ }^{65}$ Chaibi, supra note 14 , at 381.

${ }^{66}$ Duquette, supra note 8, at 188-89.

${ }^{67}$ William Bradford, The Western European Union, Yugoslavia, and the (Dis)Integration of the EU, The New Sick Man of Europe, 24 B.C. InT'L \& Comp. L. REv. 13, 15-16 (2000).

68 TEU, supra note 19, at art. 42.

69 Treaty of Lisbon, supra note 42, at art. 28A.7 ("If a Member State is the victim of armed aggression on its territory, the other Member States shall have towards it an obligation of aid and assistance by all the means in their power.”); European Policies: Common Foreign and Security Policy, supra note 18.
} 


\section{Eurocorps and the RRF}

Implementing a common foreign policy requires a military structure. Two efforts exist: the Eurocorps and the Rapid Reaction Force ("RRF”). The Eurocorps began as a joint Franco-German force, though Belgium, Luxembourg, and Spain joined some time later. Some operational difficulties arose due to language and equipment differences. ${ }^{70}$ The RRF is perhaps the beginning of a European army. The units in the RRF are maintained by the member states and are intended for rapid sustained deployments: sixty days to deployment, with deployments of up to one year. ${ }^{71}$ However, RRF deployment decisions are made by the member states. Although the RRF participated in the "Concordia mission," 72 the EU does not yet have its own military means to enforce its policies and is dependent on the member states.

\section{FOREIGN POLICY INSTRUMENTS}

\section{A. Declarations}

Europe's foreign policy, expressed in the decisions and common positions, is communicated to third parties in "declarations following the meetings of the Ministers or the Heads of Governments, demarches with a third state, diplomatic missions entrusted to the President-in-Office, or common positions adopted in international for a."73 Europe, when it formulates its will, can express that will to foreign states clearly. Of course, declarations are "just talk," but talking is an essential part of diplomacy. However, if diplomacy fails then "actions speak louder than words.”

\section{B. Sanctions and Foreign Aid}

The European Union can, and does, successfully use sanctions to assert its common foreign policy. Sanctions may be political, diplomatic, cultural, or economic. For example, economic sanctions were undertaken against Bosnia. ${ }^{74}$ Trade may be restricted, as was done to Haiti, ${ }^{75}$ or investments withdrawn or frozen, as is happening in Iran. Goods can be embargoed, ${ }^{76}$ as took place, for example, in Sudan. ${ }^{77}$ Syria is currently subject to EU sanctions

${ }^{70}$ Opi \& Floyd, supra note 3, at 328.

${ }^{71}$ Id. at 327.

72 EU Force Takes over Peace Role, The Guardian, (Mar. 30, 2003, 10:39 PM), http://www.theguardian.com/world/2003/mar/31/balkans.eu (last visited Apr. 1, 2015).

${ }^{73}$ Stein, supra note 25, at 985.

${ }^{74}$ Ward, supra note 2, at 11.

${ }^{75} \mathrm{Id}$.

${ }^{76}$ Chaibi supra note 14 , at 372.

${ }^{77}$ Ward, supra note 2, at 11. 
along with Iran. ${ }^{78}$ Russian individuals and firms have been subjected to targeted sanctions due to Russia's illegal annexation of Crimea. Russia also faces sectoral sanctions of entire industries, which will be imposed if Russia annexes further Ukrainian territory or continues its illegal covert military actions in Ukraine.

While sanctions may dissuade Russia from further illegal annexation of Ukrainian territory, they likely will not force Russia to restore or share sovereignty over Crimea with Ukraine. However, existing sanctions against Russian individuals will not be lifted until the Crimean annexation is resolved. Sanctions do work, but may take time to have their desired effect.

Just as Europe can impose economic sanctions, it can also offer foreign aid as a tool in its foreign policy - tax privileges, subventions, loan guaranties, and humanitarian assistance are the varieties of economic aid. For example, aid was offered within Europe to Bosnia and outside of Europe to South Africa, Palestine, and Nigeria. ${ }^{79}$

\section{INTERVENTION: PEACEKEEPING}

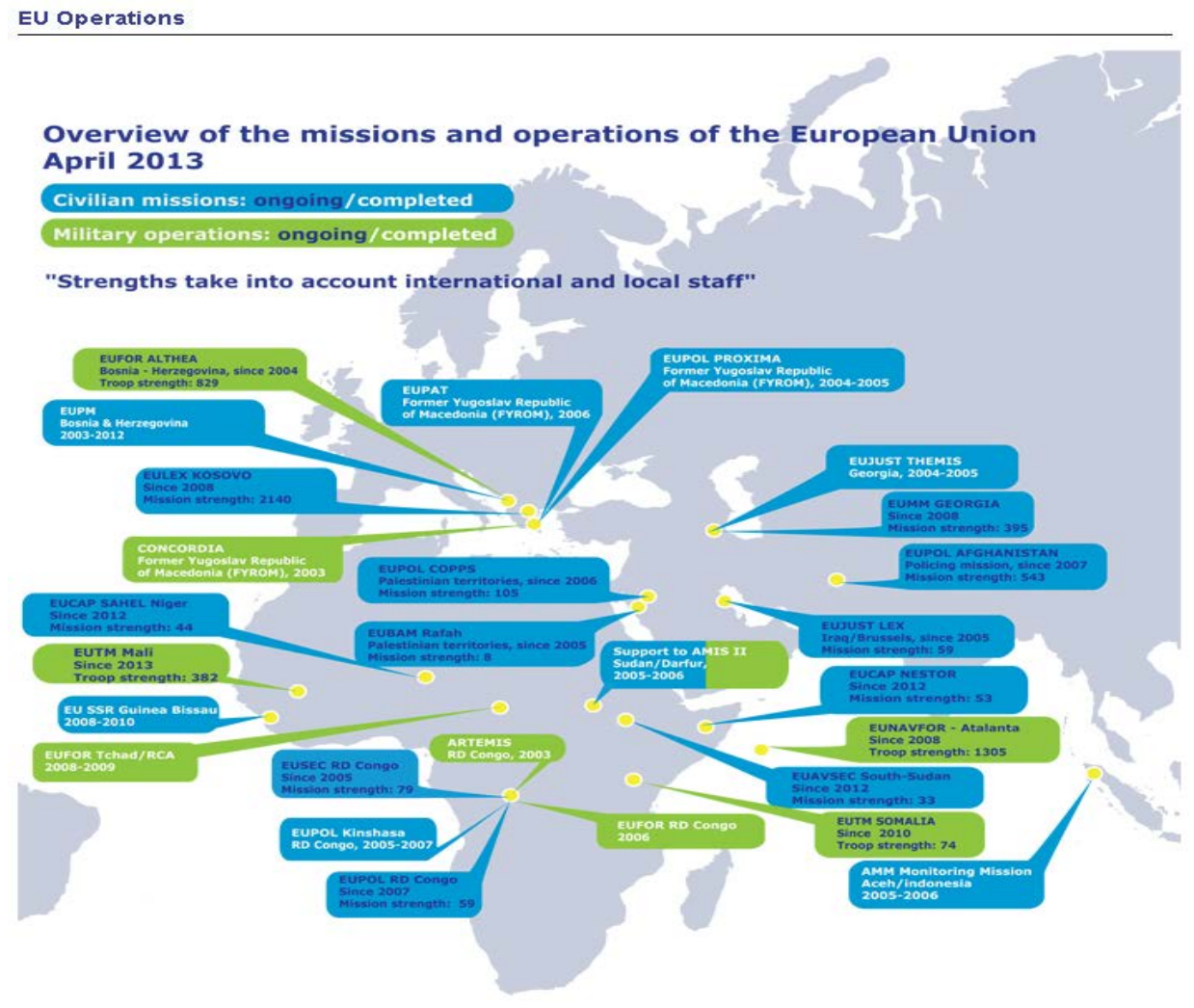

${ }^{78}$ E.g., Council Decision 2011/235/CFSP, 2011 O.J. (L 100) 51 (EU).; Council Regulation 359/2011, 2011 O.J. (L 100) 1 (EU); Council Decision 2010/413/CFSP, 2010 O.J. ( L 195) 39 (EU).

${ }^{79}$ Ward, supra note 2, at 10. 
Map of EU Missions ${ }^{80}$

Although the most effective instruments of EU foreign policy are likely financial incentives and disincentives, the European Union has also participated in military peacekeeping missions. The European Union engages in international peacekeeping by sending military force overseas to maintain public order and promote democracy and human rights. ${ }^{81}$ The first peacekeeping operation was the European Union Police Mission ("EUPM") in Bosnia and Herzegovina, lasting for three years and including five hundred police officers from more than two dozen countries, fifteen of which are EU Member States. ${ }^{82}$ Afterwards, the "Concordia" peacekeeping mission was launched on March 18, 2003 in Macedonia (ex-Yugoslavia). NATO cooperated both in planning and providing assets for the "Concordia mission." 83 The "Artemis" mission in the Democratic Republic of Congo ("DRC”) under U.N. mandate did not involve NATO, but rather only EU forces ${ }^{84}$ More recently, the European Union has conducted, among others, operations in Somalia ${ }^{85}$ (naval interdiction of pirates) and Chad $^{86}$ (security/development aid), which are illustrated in the graphic above.

These external actions show the ability of the European Union to engage in a common foreign policy throughout the conflict spectrum ${ }^{87}$ when there is sufficient unity among the Member States. Much of this activity occurred at a time when EU foreign policy was regarded as incoherent and ineffective. ${ }^{88}$ The errors from past campaigns, such as those made in Yugoslavia, remain in memory, so that the same errors will not be repeated in Syria or Ukraine. The success stories are less well known, but empirically, are more numerous.

80 Map of EU Missions, Council of THE EuRopeAn Union, availible at http://www. consilium.europa.eu/eeas/security-defence/eu-operations (last visited May 11, 2015).

${ }^{81}$ Chaibi, supra note 14 , at 374.

${ }^{82}$ Id. at 379.

${ }^{83} \mathrm{Id}$.

${ }^{84} I d$.

85 EU Naval Force Warships Assist 2 Merchant Vessels after Freedom from Pirates, 69 EU SECURITY AND DEFENCE NEWS, Mar. 15, 2013, available at http://www.consilium.europa.eu/ uedocs/cms_data/docs/pressdata/en/esdp/136271.pdf; EU Naval Force, EU SECURITY AND DEFENCE NEws, 2013, available at http://www.consilium.europa.eu/eeas/security-defence/euoperations/eunavfor-somalia?lang=en.

${ }^{86}$ European Union, EUFOR Tchad/RCA,EU SECURITY AND DEFERENCE NEWS, June 2012, available at http://www.consilium.europa.eu/uedocs/cms_data/docs/pressdata/EN/foraff /130781.pdf; See generally EUFOR Tchad/RCA; European Union, EUFOR Tchad/RCA, available at http://www.consilium.europa.eu/eeas/security-defence/eu-operations/completedeu-operations/eufor-tchadrca.

${ }^{87} \mathrm{Id}$.

${ }^{88}$ Chaibi, supra note 14 , at 380. 


\section{HISTORICAL EXPERIENCES OF EU FOREIGN POLICY}

We can analyze the experiences of EU foreign policy in historical order to see the trends. The trend is toward quantitative, not qualitative, improvements in the coherence and cohesion of EU foreign policy. We have seen neither the "catalytic" effects of the European Union causing a sudden and more rapid integration (change in degree), nor a "quantum" effect causing a radical alteration in state (change of type) from coordinated foreign policies to a single European foreign policy. At the same time, we do see a clear trend of increasing integration of foreign policies of the Member States. If the common European foreign policy makes the quantum leap from a coordinating system for managing consensus to an operational system for implementing united policy, such a change would most likely result from Russia's illegal annexation of Crimea The annexation constitutes a violation of the universally recognized principle of the territorial integrity of each state and Russia's treaty obligations These violations that could result in the focusing of common European and indeed transatlantic willpower.

\section{A. Falklands}

An early distant experience in European (at the time European Community) foreign policy was also one of the most successful. In 1982, Argentina attacked the Falkland Islands, resulting in a war with Britain. "[A]t the outbreak of the Falkland war, an economic embargo against Argentina was ... [ [adopted by the] Community, employing its common trade policy power." 89 The result was mixed; "the member states initially provided solid support for the British action in the Falkland Islands/Malvinas War by agreeing to Community sanctions against Argentina, but the unanimity fell apart for individual political reasons once the sanctions came up for extension." ${ }^{90}$ Despite that limitation, the Falklands crisis was, in comparison with the Yugoslavian crises, a success for European foreign policy.

\section{B. Yugoslavia}

The next major test of EU foreign policy was the crises in Yugoslavia (particularly in Bosnia, Croatia, Serbia, Kosovo and Macedonia). EU foreign policy singularly failed to prevent the conflicts and was unable to end them once they began. This bodes ill for Syria, where we see a similarly explosive ethnic mix of conflicts. Furthermore, Yugoslavia set the stage for Ukraine, as Russia felt aggrieved by the outcomes in Yugoslavia, which were not those desired by Russia. However, in the 1990s Russia was an impoverished

\footnotetext{
${ }^{89}$ Stein, supra note 25, at 985-86.

${ }^{90}$ Note, A Community Within the Community: Prospects for Foreign Policy Integration in the European Community, 103 HARV. L. REV. 1066, 1073 (1990).
} 
powerless kleptocracy, and did not contribute positively to tenable solutions. In Bosnia, the debate about how to react to the crises was frozen by the question of who should be responsible to solve the problem: NATO? The now defunct WEU? Member states? Europe? The United States? ${ }^{91}$ As a result, violence was not prevented or stopped as quickly as it could have. Ultimately, the United States intervened ${ }^{92}$ because of Europe's paralysis. ${ }^{93}$ To prevent or end such crises requires both a united will and military forceand Europe lacked both. ${ }^{94}$ When a similar crisis played out again in Kosovo just a couple of years later in 1996, there was less diplomatic confusion but still no real European military capacity. Russia was unable to contribute positively to a resolution of conflict in Kosovo, due to poverty resulting from a corrupt kleptocracy, and so Russia feels aggrieved at the outcome in Kosovo. Russia attempts to justify its illegal annexation of Crimea by the fact that Kosovo seceded; however, Kosovo was not immediately annexed by a large neighbor, nor were grave human rights abuses occurring in Crimea. The Russian efforts to try to justify its illegal annexation are simply untenable as a matter of law. In Kosovo, the incoherence and incapacity of Europe to react adequately, or at all, to a crisis right on its own doorstep discredited the EC as a foreign policy actor because this incoherence resulted in needless slaughter of innocent civilians. "Bosnia-Herzegovina . . . illustrated that the Western European ability to formulate and implement a CFSP still was far too meager in the absence of U.S. leadership and even, on occasions, unilateralism." ${ }^{55}$ Thus, it is clear that the European Union "must develop a coherent defense identity and defense institutions to orchestrate the management of contingencies such as Yugoslavia." ${ }^{66}$ The CFSP was created because of the failure of the European Community in Yugoslavia, ${ }^{97}$ and now faces similar challenges in Syria and Ukraine. As to the challenge in Ukraine, it seems that the "Weimar Triangle" approach is effective, though no similar initiative has yet appeared for managing the crisis in Syria.

\section{THE "LONG WAR"}

In his book 1984, George Orwell famously predicted that large empires would throw themselves into permanent wars in order to distract the people from their poverty and to give them a common enemy so as to deflect potential conflict against the government toward a common enemy. Putin has

\footnotetext{
91 Bradford, supra note 67, at 27.

92 Opi \& Floyd, supra note 3, at 318.

${ }^{93}$ Id. at 319.

${ }^{94} \mathrm{Id}$.

${ }^{95}$ Bradford, supra note 67, at 53.

${ }^{96}$ Id. at 14.

${ }^{97}$ Cf. Opi \& Floyd, supra note 3, at 304-05 (stating that the dissolution of Yugoslavia "highlighted areas needing improvement and sparked the creation of the CFSP").
} 
clearly embraced the idea that Russia is somehow locked into a "clash of civilizations." Fascists have long known the power of terrorism to unite the people and distract them from their tyrannical government. We should skeptically and critically regard those who think that the world is somehow locked into an inevitable "clash of civilizations" and that "we" are trapped in a "long war." War is a man-made disaster, and because war is man-made, war can be stopped by men.

\section{Afghanistan}

The European Union did not participate in the war in Afghanistan because its foreign and security competence in the EU Treaty ${ }^{98}$ was limited to humanitarian and rescue tasks, and its security competence and did not include collective self-defense. ${ }^{99}$ The Treaty of Lisbon now provides explicitly for mutual assistance in the event of an armed attack. ${ }^{100}$

\section{IRAQ}

United States unilateralism, in instigating the second Iraq war, "dramatically raised the level of transatlantic conflict even as it deepened political fault lines within an expanding European Union." 101 Those internal splits within the European Union led to a paralysis in the CFSP: "Europe does not have a common vision of the world, nor does it have foreign policy instruments matching its economic strength.” ${ }^{102}$ Thus:

Europe may be characterized as an economic giant, a political dwarf and a military worm. Not once has the European Union succeeded in attaining the status of a superpower — not in the Near East or in Africa, nor in Former Yugoslavia, and not even in Cyprus. In all these cases,

\footnotetext{
98. Jan Wouters \& Frederik Naert, The European Union and 'September 11', 13 IND. INT'L \& Comp. L. ReV. 719, 769 (2003).

99 TEU, supra note 19, at art. 17. TEU included "humanitarian and rescue tasks, peacekeeping tasks and tasks of combat forces in crisis management, including peacemaking” in security and foreign policy. TEU art. 43 para. 1 specifically provides that "these tasks may contribute to the fight against terrorism, including by supporting third countries in combating terrorism in their territories."

100 Treaty of Lisbon, supra note 42, at art. 28A.7 provides “"if a Member State is the victim of armed aggression on its territory, the other Member States shall have towards it an obligation of aid and assistance by all the means in their power." European Policies: Common Foreign and Security Policy, supra note 18.

101. Cafruny, supra note 58, at 329.

102. Chaibi, supra note 14 , at 359.
} 
Europe was helplessly stranded. ${ }^{103}$

Those facts underscore the importance of building a cohesive common European foreign and security policy to meet the obvious challenges facing Europe in Syria and Ukraine so that the history of paralysis and needless deaths shall not repeat.

\section{LIBYA}

In Libya, the EU CFSP machinery showed its possibilities and also its limitations. ${ }^{104}$ Militarily, on the basis of a U.N. Security Council resolution, the United States, Britain, and France decisively intervened in the Libyan rebellion with airpower, enraging Vladimir Putin, President of the Russian Federation, who regarded the bombardments as unauthorized by the terms of the relevant Security Council Resolution and as creating chaos and the risk of terrorism rather than stability. The death of the U.S. Ambassador to Libya as a result of that intervention underlines Putin's point. It is thus completely unsurprising that the Russian Federation has thereafter refused, repeatedly, to authorize any Security Council resolution with regard to Syria or Ukraine.

In Libya, the European Union itself was militarily irrelevant. ${ }^{105}$ The CSFP machinery was simply too slow to be able to react appropriately, let alone to take initiative and act decisively. In contrast, politically, the European Union was able to use its CFSP machinery to evacuate European citizens from Libya, deliver humanitarian aid, and impose sanctions successfully. ${ }^{106}$

\section{SYRIA}

The rebellion in Syria may be compared to the disintegration of Yugoslavia in several respects. First, the international community finds itself paralyzed. Second, this paralysis seems to be in large part a reiteration of Cold War patterns of conflict between the United States and Russia; like Serbia, Syria is a Russian ally. Third, Syria's internal divisions may result in the splitting of Syria into three (or more) successor states. Fourth, and most

\footnotetext{
103. Muschwig, supra note 23, at 21.

104 See generally Anand Menon, European Defence Policy from Lisbon to Libya, SURVIVAL: Global Pol. \& StRATEgY, June-July 2011, at 75 (2011).

105 See generally DPA, Diplomats Mourn 'Death' of EU Defence Policy over Libya, ATL. CouncIL (March 24, 2011), http://www.atlanticcouncil.org/blogs/natosource/diplomatsmourn-death-of-eu-defence-policy-over-libya.

106 “The EU's response to the Libyan crisis was not generally weak or ineffective. The EU has been praised for its quick and substantial delivery of humanitarian aid and for its far-reaching sanctions regime. However, these accomplishments have been dwarfed by the lack of vertical consistency and coherence in other policy fields.” Nicole Koenig, The EU and the Libyan Crisis - In Quest of Coherence?, 46 InT'L SPECTATOR: ITALIAN J. INT'L AfF. 11, 24 (2011).
} 
disturbingly, we are seeing repeated grave human rights abuses. Unlike Yugoslavia or Ukraine, however, the risk of terrorism is added to the equation. Unfortunately, as in the case of Yugoslavia, the European Union is showing itself to be ineffective at managing or even reacting to the conflictpartly because of the paralysis at the U.N. Security Council, partly because there are definitely conflicting tendencies among the Member States at how best to address the failure of the Security Council to effectively try to solve the problems Syria presents. The European Union ${ }^{107}$ and its member states, ${ }^{108}$ pursuant to Article 215 of the Treaty on the Functioning of the European Union ("TFEU"), ${ }^{109}$ have imposed "far reaching and sophisticated sanctions operations in support of the protests against the current regime in Syria." 110 However, it is the author's opinion that the European Union will be unable to effectively mediate between the Syrian rebels and the Syrian government or between the United States and Russia. I expect no peaceful solution in Syria due to the polarization of Russia against the United States due to Russia's illegal annexation of Crimea.

\section{NORMATIVE RECOMMENDATIONS}

Given the European disunity and lack of means, some commentators suggest that transatlantic relations should focus U.S. attention on security issues and European attention on development, ${ }^{111}$ because "the European Union 'speaks softly and carries a big carrot."” 112 Thus, “[i]t has become fashionable to argue for the continuation of a 'good cop, bad cop' approach, with the European Union sweet-talking the terrorists and dictators, whilst the

107 Council Regulation 36/2012 (EU), of January 2012, Concerning Restrictive Measures in View of the Situation in Syria and Repealing Regulation (EU) No 442/2011, 2011 O.J. (L 16) 1, available at http://eur-lex.europa.eu/LexUriServ/LexUriServ.do?uri=OJ:L:2012:016: 0001:0032:EN:PDF.

${ }^{108}$ E.g. Export Control Order, 2008, S.I. 2008/3231, sch. 4, pt. 2 (Outlining embargo of Syria; Export Control (Syria Sanctions) and (Miscellaneous Amendments) Order, 2012, S.I. 2012/810. See also, U.K., Dep't for Bus., Innovation \& Skills, Foreign \& Commonwealth Office, Embargoes and sanctions on Syria: Information on embargoes on Syria and how to apply for an export licence, GOV.UK, https://www.gov.uk/sanctions-on-syria (last updated Jan. 28, 2015).

109 "Article 215 of the Treaty on the Functioning of the European Union (TFEU) provides a legal basis for the interruption or reduction, in part or completely, of the Union's economic and financial relations with one or more third countries, where such restrictive measures are necessary to achieve the objectives of the Common Foreign and Security Policy (CFSP)." European Comm'n, Restrictive measures in force (Article 215 TFEU), 1, available at http://eeas.europa.eu/cfsp/sanctions/docs/measures_en.pdf.

${ }^{110}$ Clara Portela, The EU's Sanctions Against Syria: Conflict Management by Other Means, SECURITY Pol'y BRIEF (Egmont Royal Inst. for Int'l Relations, Brussels) Sept. 2012, at 1, available at http://www.egmontinstitute.be/wp-content/uploads/2013/09/SPB38.pdf.

${ }^{111}$ E.g., Ward, supra note 2, at 38.

112 Id. 
United States and NATO hover menacingly in the background threatening apocalyptic intervention." 113 If that is the contribution that Europe can make to a more peaceful and prosperous world then:

[T]he Union should seek to develop its security and defense policy by relying upon the constitutional idiosyncrasies of its current structure [...][and by acknowledging] acknowledge the need for new challenges to be addressed on the basis of a variety of legal instruments that would transcend traditional legal categorizations and whose combined effect would enhance the stature of the EU. Therefore, the economic aspects of security should be brought to the center [...] . . . and dealt with as a matter of priority on the basis of the sophisticated, multi-layered approach advocated by the Commission. ${ }^{114}$

\section{CONCLUSION}

Europe has instruments with which it may exert pressure on or assist foreign governments and a coordination structure to form and implement a common foreign policy - these are real forms of soft power. The CFSP will, with time, increasingly enable Europe to contribute to building a stable and prosperous world. The CFSP serves the economic and aspirational ${ }^{115}$ common interests and goals of the Member States ${ }^{116}$ : open markets, the rule of law, protection of human rights and democracy. Those goals are mutually supporting and coherent. As the global economy grows more interdependent, political interests worldwide will continue to converge ${ }^{117}$ even though it faces crises in the short term in Syria and Ukraine. Deepening of European political integration, including the further integration of Ukraine in Europe, is thus inevitable. The CFSP will continue to improve coordination of the foreign policy of the Member States using the functionalist method; increased experience will also deepen future integration. However, the decisive will of the political leaders of the European Union is also needed to foster and hasten this inevitable process by forming coherent policies that realistically match aspirations with abilities. Europe needs visionary leaders able to marshal competing movements and direct them to coherent desired goals of peace through prosperity and the rule of law to attain a better world for all.

\footnotetext{
113 Id. at 46.

${ }^{114}$ Koutrakos, supra note 13, at 95 (citation omitted).

${ }^{115} \mathrm{Id}$. at 20.

${ }^{116}$ Muschwig, supra note 23, at 19.

${ }^{117}$ See generally Ward, supra note 2, at 40-41.
} 
